\title{
Research
}

\section{Valuing the Provisioning Services of Wetlands: Contrasting a Rural Wetland in Lesotho with a Peri-Urban Wetland in South Africa}

\author{
$\underline{\text { Kathryn S. M. Lannas }}^{1}$ and $\underline{\text { Jane K. Turpie }}^{1}$
}

\begin{abstract}
Given that few studies have valued the provisioning services of temperate southern African wetlands, research on this topic was undertaken in a remote rural wetland, Letseng-la-Letsie, in Lesotho and a peri-urban wetland in Mfuleni, Cape Town. The objectives were to quantify incomes from wetland resources, assess the relative dependency of communities on wetland provisioning services, and estimate the total provisioning value of the wetlands. Data were collected from informal interviews and structured household surveys. Despite the different settings, both wetlands were used mainly for grazing livestock. The estimated total value added during 2007 from grazing was U.S. \$180,078 for Letseng-la-Letsie and U.S. \$540,286 for Mfuleni. Letseng-la-Letsie and Mfuleni were also used for hunting, and Mfuleni was partially cultivated. Even though the local wetlands were easier to access from Mfuleni, only $13 \%$ of households used them, compared with $65 \%$ in Letseng-la-Letsie. However, the households around Letsengla-Letsie derived less of their income (6\%) from the wetlands, compared with $82 \%$ in Mfuleni. This reflects the more specialized livelihood strategies in the urban compared with the rural setting, in which riskspreading household production strategies were more prevalent. The loss of the wetland in Letseng-laLetsie would therefore potentially affect more people but have less of an effect on the finances of individual households than in Mfuleni. It is estimated that U.S. \$220/ha and U.S.\$1765/ha is derived annually from wetland provisioning services in Letseng-la-Letsie and Mfuleni, respectively. A standard protocol is needed for valuing wetlands in southern Africa.
\end{abstract}

Key Words: wetlands; provisioning services; dependency; livelihoods; grazing; Lesotho; South Africa; peri-urban areas

\section{INTRODUCTION}

Wetlands provide a range of goods and services and possess a variety of attributes of value to society (Barbier 1993). They offer provisioning, regulating, cultural, and supporting services (Millennium Ecosystem Assessment 2005) that generate economic value from their direct, indirect, or potential use. Nevertheless, despite legislation designed to protect them, wetlands continue to be degraded and lost at an alarming rate (Turner et al. 2000). This is at least partly because of a lack of understanding of their ecological and socioeconomic importance, which leads to distorted policy and decision making regarding their use and management (Adaya et al. 1997, Smit and Wiseman 2001, Terer et al. 2004).
In southern Africa, many wetlands have been lost or degraded as a result of increasing demands for land and water. An understanding of the socioeconomic value of wetlands is crucial when deciding on conservation and development priorities related to land use and the allocation of scarce water resources. Therefore, the value of the natural resources that wetlands provide to poor communities is a critical consideration. These resources include rich, moist soils for cultivation; grazing for livestock; fisheries; reeds, sedges, and grasses for crafts and timber; and water for domestic use, watering livestock, and irrigation (Kotze and Breen 1994). It is estimated that millions of rural South Africans are dependent on natural resources for their daily survival (Wynberg 2002). 
This study investigated the provisioning values of two temperate southern African wetlands that differ markedly in their ecological characteristics and their geographic and social settings. The first wetland, Letseng-la-Letsie, is a high-altitude mire in rural Lesotho, and the second is a collection of depression wetlands surrounded by the peri-urban township of Mfuleni in Cape Town, South Africa. These wetlands fill gaps in the international literature, which is dominated by valuation studies of mangroves, floodplains, deltas, and estuaries (Sathirathai 1997, Turpie 2000, Kangalawe and Liwenga 2005, Turpie et al. 2006), and also provide data on inland wetlands south of the Zambezi basin.

The aim of this study was to describe and compare the use and value of the provisioning services of the two wetlands and to compare their importance in the livelihoods of the two types of communities surrounding them.

\section{Study areas}

\section{Letseng-la-Letsie wetland, Lesotho}

Wetlands in the Lesotho highlands are classified as mires (Zunckel 2003). The Letseng-la-Letsie wetland located in the Quthing Province, Lesotho (Fig. 1), is the source of the Mohlakeng River, a tributary of the Quthing River. The 819-ha wetland is a Ramsar site but is used for livestock grazing. Part of the wetland is permanently inundated because of a small dam at its outflow point. There are 18 villages in the vicinity of the wetland with a total population of about 12,000 people. The closest town, Mphaki, has a population of about 940 . Based on interviews with village headmen, there are an estimated 4070 households in the study area.

Land in Lesotho belongs to the king (Morris et al. 1989). Grazing areas are communal and controlled primarily by local chiefs (Letsela et al. 2002). As a Ramsar site, Letseng-la-Letsie is governed nationally by the Ministry of National Resources, then locally by the governing bodies of the Quthing District and the nearest village (Ministry of Natural Resources 2006). Communities in the remote mountainous areas are highly dependent on agriculture and natural resources and reportedly use wetlands to harvest various natural resources (Ministry of Natural Resources, unpublished manuscript).

\section{Mfuleni Wetlands, Cape Town, Western Cape}

The township and associated informal settlements of Mfuleni fall within the Kuils River floodplain of greater Cape Town. Originally seasonal (Shand and Nicks 1999), the Kuils River is now perennial because of urban runoff. Around Mfuleni there are both seasonal and permanent wetlands covering some 311 ha (Fig. 2).

Most land in Mfuleni is state owned or previously belonged to the South African Development Trust (Dixon and Ramutsindela 2006). Past studies list a number of resources harvested from open areas in the City of Cape Town, including medicinal plants, food plants such as Aponogeton distachyos, animals, arum lilies (Zantedeschia aethiopica), and Phragmites reeds (Turpie et al. 2001). Shand and Nicks (1999) estimated that 62 plant species are harvested from the wetlands of the Kuils River. Cattle are also grazed on the wetlands. Mfuleni was originally a temporary residence area for migrant workers (Dixon and Ramutsindela 2006). The area did not have informal settlements until 1990, when squatter housing was established as people fled to escape violence elsewhere. In 2001, Mfuleni had a population of about $22,885,57 \%$ of whom were unemployed, and $79 \%$ of the population earned less than U.S. \$230/month (Statistics South Africa 2001a). After floods in 2001, more than 4000 people were resettled on open areas in Mfuleni (Dixon and Ramutsindela 2006). There are 7517 households in Mfuleni, of which 1117 are in informal settlements. Informal settlement dwellers are the main users of the wetland areas.

\section{METHODS}

\section{Preliminary data gathering}

General wetland use was assessed using rapid appraisal methods (Nichols 1991). Informal discussions identified resources used by surrounding communities, their property rights and allocation, and numbers of households. Estimates of current prices for livestock, crops, and crafts were obtained, and farming practices were described. For Letsengla-Letsie, informal discussions were held with village headmen and residents, and with herders. In Mfuleni, key informants included the president of the local livestock co-operative, a traditional healer, and representatives of different age groups. 
Fig. 1. Location of the Letseng-la-Letsie wetland in Lesotho.

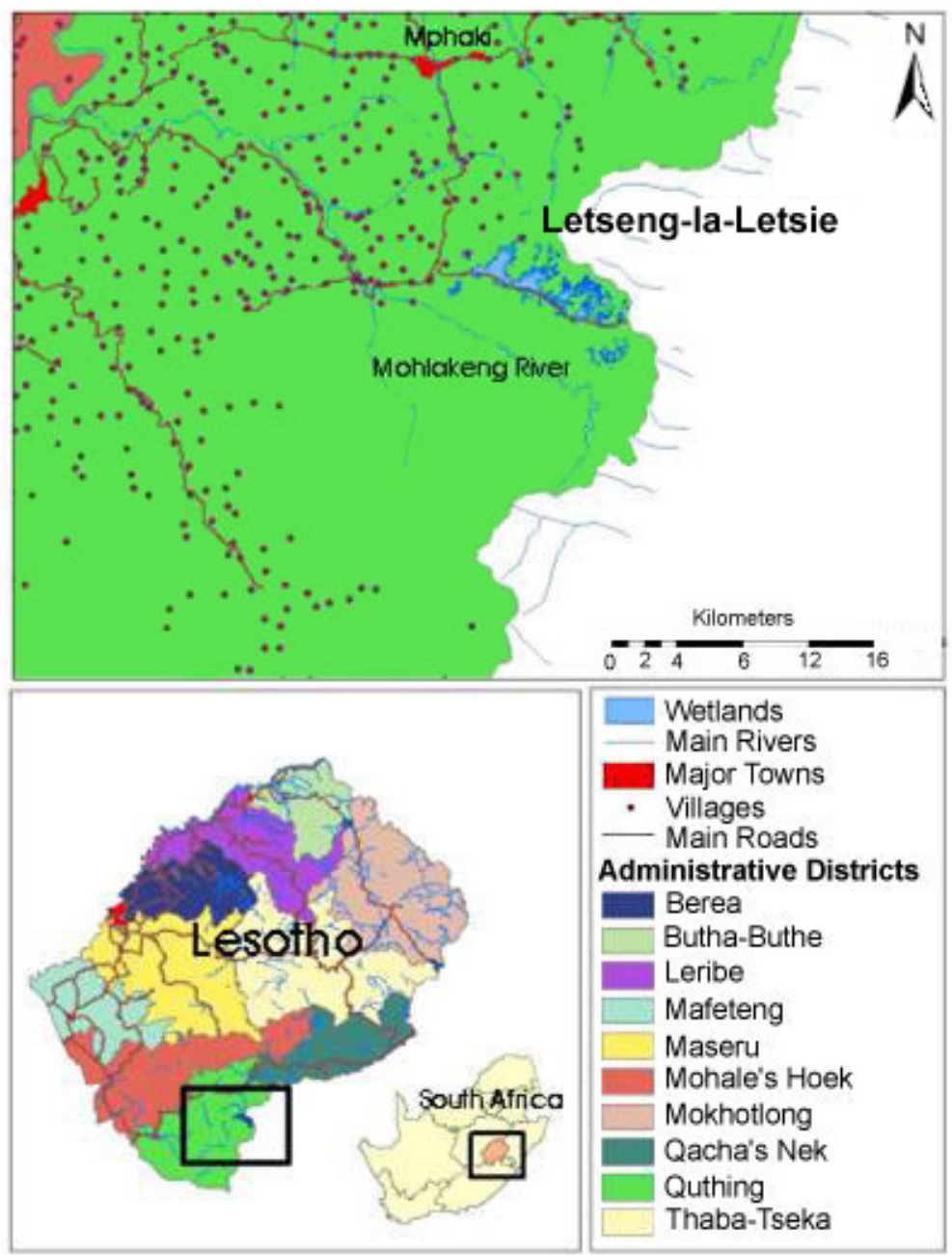

\section{Household surveys}

The initial findings guided the design of a household questionnaire that was used to collect quantitative data on resource use and income. Questionnaires were translated into the local vernacular (Sesotho and Xhosa, respectively) and administered by native speakers trained as enumerators. In each village, the number of households surveyed was determined by the size of the village, and households were randomly selected by dividing the villages into sections and surveying a sample of households from each section. A total of 161 households was surveyed around Letseng-la-Letsie from April to May 2007, and 280 households were surveyed in the informal settlements of Mfuleni from June to September 2007.

Data were collected on: (1) household demography; (2) type of housing, fuel, lighting, and heating; (3) main sources of income and earnings; (4) field sizes and, if the wetland was used, crops, harvests, and sales, including how the last harvest compared to other years; (5) livestock owned, slaughtered, given to herders, and sold as well as milk and egg production and income from wool and mohair sales; (6) natural resource harvests, proportion from wetlands, craft production and sales; and (7) sources and use of water. 
Fig. 2. Location of wetlands around the township of Mfuleni in Cape Town.
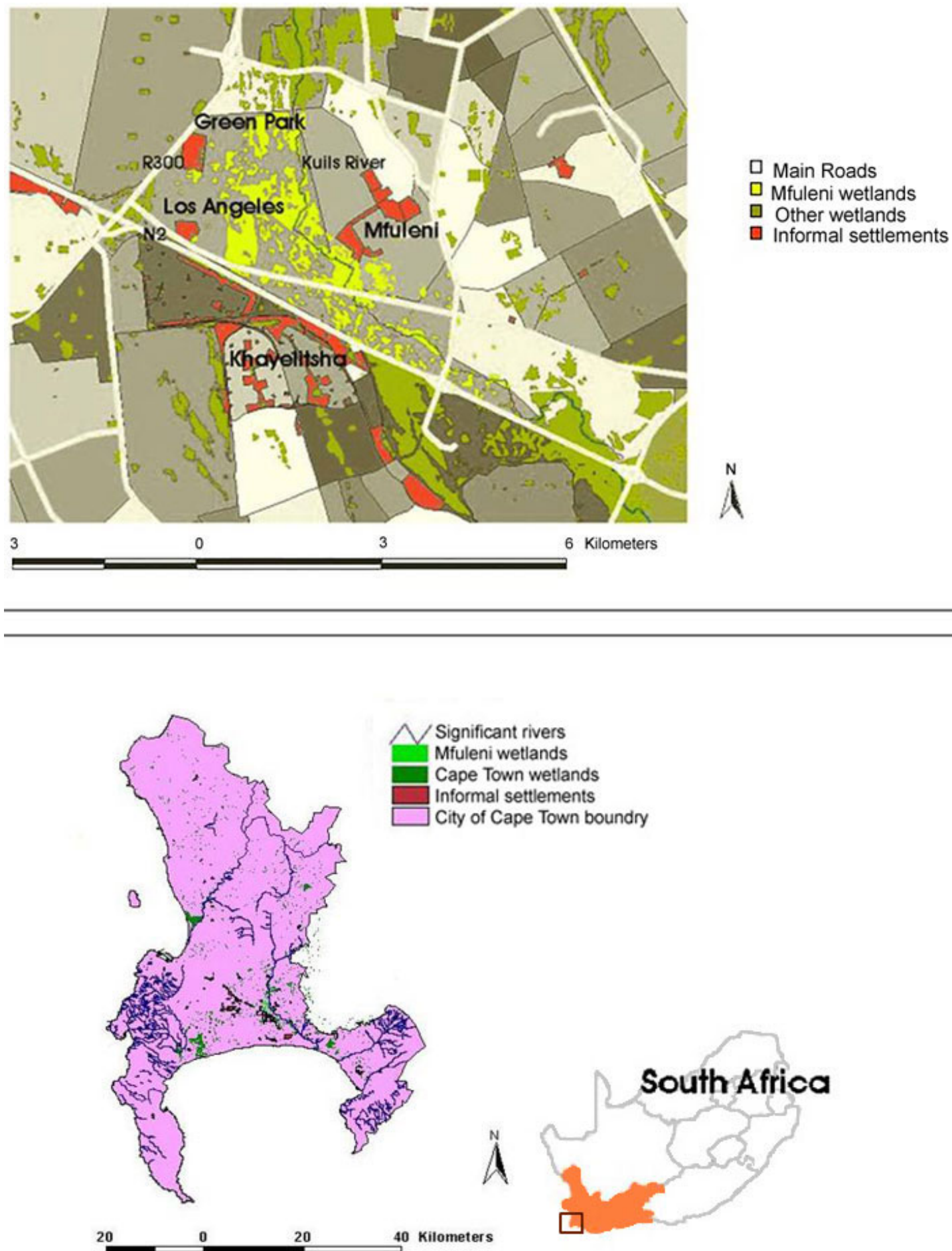


\section{Data analysis}

Statistical analysis was carried out using Statistica 8.1 (StatSoft, Inc., Tulsa, Oklahoma, USA). One questionnaire from Mfuleni was discarded because its content was questionable. The currencies, Maloti in Lesotho and Rand in South Africa, were equal and equivalent to about U.S. \$0.14 in 2007.

The annual value of wetland-based activities to households was evaluated in terms of average gross, net, and cash household incomes. Gross incomes from agriculture and natural resources were estimated on the basis of average harvests and prices, irrespective of what proportion was sold, $i$. e., valuing subsistence consumption at market prices. Net income took input costs of seeds, hired labor, and capital into account. Cash income was based on sales only. The economic value added to national income was calculated by using current market prices and excluding capital and labor because they are internal inputs (Gittinger 1982). Price distortions in the form of input subsidies were corrected.

\section{Estimating income derived from the wetlands}

For Letseng-la-Letsie, the proportional contribution of the wetland to grazing was based on existing estimates of the carrying capacities of the wetland and surrounding grassland areas. The carrying capacity of wetlands in the region of Letseng-laLetsie is approximately 4 ha/LSU (large stock unit; Morgenthal et al. 2004), and grasslands reportedly have half the carrying capacity of wetlands (Grab and Morris 1997). Based on the relative areas involved, the wetland supplies about $5.2 \%$ of the estimated total grazing capacity of the area, or some 3963 LSU, which is considerably lower than the current stocking rate.

Because wetlands provide the only opportunity for agriculture around Mfuleni, all income from this activity was attributed to the wetland. In the case of grazing, the wetlands contributed about $90 \%$ of the grazing land, which was supplemented by road verges.

\section{Dependence}

The level of dependence on the wetlands was estimated in terms of the percentage of overall household incomes derived from them. Because there are no regional measures of poverty for Lesotho and South Africa, dependence was related to the Human Development Index. This measures life expectancy, education levels, and overall welfare in a given area (Statistics South Africa 2001b).

\section{Overall value of the wetlands}

The overall annual value of the wetlands was determined from the aggregate of the income derived by households from the wetlands:

$$
\text { Value of Wetland }=\sum_{\mathrm{ps}} \% \mathrm{hh}_{\mathrm{ps}} \times \mathrm{HH} \times \mathrm{V}_{\mathrm{ps}}
$$

where ps represents the different wetland provisioning services, \%hh is the percentage of surveyed households using the particular provisioning service, $H H$ represents the total number of households around the wetland, and $V_{\mathrm{ps}}$ is the average income earned per user household from the wetland provisioning service. This equation was used to calculate the total gross, net, and cash income values of the wetlands and the economic value added by wetland provisioning services.

\section{RESULTS}

\section{Household characteristics}

Households around Letseng-la-Letsie were relatively large (mean $=7, \mathrm{SD}=4$ people), often consisting of extended families with reasonably high numbers of children. Average household sizes in Mfuleni did not differ significantly from those around Letsengla-Letsie (mean $=7, \mathrm{SD}=5$ people) and had similar compositions in the different age groups. Of the households surveyed around Letseng-la-Letsie, $98 \%$ had traditional houses, and $75 \%$ of these had thatched roofs. In Mfuleni, $87 \%$ of the households surveyed lived in informal housing consisting of 
makeshift houses with one or two rooms. The remaining households lived in formal housing. Around Letseng-la-Letsie, the major form of heating was firewood $(51 \%)$, with a much lower percentage of households using paraffin heaters $(12 \%)$. In Mfuleni, the reverse was found, with more households using paraffin heaters $(58 \%)$ and a smaller percentage using firewood (16\%). The highest percentage of households around Letsengla-Letsie used firewood for cooking, whereas around Mfuleni more people used paraffin stoves.

The average annual household income around Letseng-la-Letsie was U.S. \$771 (SE = U.S. \$136), with $30 \%$ of surveyed households including members who were formally employed. In contrast, the average annual household income in Mfuleni was U.S. \$2519 (SE = U.S. \$252), and 70\% of households had a member in formal employment. The total average annual household income in Letseng-la-Letsie was significantly lower than that earned around Mfuleni $(t=-5.97324, \mathrm{df}=439, p<$ 0.05; Table 1).

\section{Natural resource use in Letseng-la-Letsie}

\section{Agriculture}

Many households did not have their own fields and participated in share cropping. Informal interviews revealed that fields were owned by families and passed down through generations. The geometric mean field size was 1.5 ha $(\mathrm{SD}=4.6 \mathrm{ha})$. Of the households surveyed, $11 \%$ felt that the previous year's harvest had been normal, but the majority felt that the harvest had been much worse than usual. Some of the reasons given were that there had been a severe frost and also insufficient rain in the preceding year. The harvests recorded were therefore lower than normal. The greatest cash income was from illegally grown cannabis (Table 2). No other purely cash crops were grown. No agriculture was carried out on the wetland.

\section{Natural resources}

Of the natural resources harvested, very few were converted to cash because most were used for subsistence (Table 3). Fewer than 5\% of the households surveyed made crafts from natural products. Brooms were manufactured from grasses, and ropes were made from sedges. None of the households harvested natural resources from Letseng-la-Letsie itself, but from surrounding areas.

\section{Hunting}

In more than $5 \%$ of the households surveyed, there were members who hunted. Of the households containing hunters, $75 \%$ used dogs for hunting, and one used a catapult. The animals that tended to be hunted the most were hares (Table 4). Only two households from the survey fished in nearby rivers and not in the wetland.

\section{Livestock}

Of the households surveyed, $62.1 \%$ owned cattle, sheep, or goats. The highest proportion of surveyed livestock owners had mixed herds of all three animals, with the next highest just owning cattle. Thirty-nine percent of the owners had livestock posts at Letseng-la-Letsie. Households were unable to graze their livestock around Letseng-la-Letsie all year because of the extremely cold winters. There was no significant correlation between household herd sizes and overall cash income for cattle and goats, but there was a significant correlation for sheep $(r=0.2798, P<0.05)$. In addition to income from selling livestock, households derived other benefits such as milk, wool, and mohair. The average amount of milk produced monthly was 190 $\mathrm{L}$, and approximately $170 \mathrm{~L}$ were sold to generate an income of U.S. $\$ 874 / y r$. Five percent of the owners rented their livestock for ploughing and earned on average U.S. \$177/yr from this. Twentythree percent of the surveyed households sold wool and earned on average U.S. \$244, and $19 \%$ of the households sold mohair, earning U.S. \$78. Because households kept different combinations of livestock, the overall net income and value added from livestock were calculated.

\section{Water use}

None of the households used water from the wetland itself. Although most had access to tap water for domestic consumption, those who used spring water tended to consume more water. Seventy percent of households used rivers to wash their clothes. 
Table 1. Sources of cash income and percentage of households receiving incomes from these sources around Letseng-la-Letsie $(n=161)$ and Mfuleni $(n=279)$; hh = households, AAI/US = annual average income for households earning U.S. dollars, and AAI/all = average annual income for all households.

\begin{tabular}{|c|c|c|c|c|c|c|}
\hline \multirow[b]{2}{*}{ Income sources } & \multicolumn{3}{|c|}{ Letseng-la-Letsie } & \multicolumn{3}{|c|}{ Mfuleni } \\
\hline & $\%$ hh & AAI/US & AAI/all & $\% \mathrm{hh}$ & AAI/US & AAI/all \\
\hline Selling home brew & 34.8 & $\begin{array}{c}275 \\
(\mathrm{SE}=68)\end{array}$ & $\begin{array}{c}96 \\
(\mathrm{SE}=26)\end{array}$ & 0.7 & $\begin{array}{c}943 \\
(\mathrm{SE}=86)\end{array}$ & $\begin{array}{c}7 \\
(\mathrm{SE}=5)\end{array}$ \\
\hline Remittances & 26.1 & $\begin{array}{c}1016 \\
(\mathrm{SE}=250)\end{array}$ & $\begin{array}{c}265 \\
(\mathrm{SE}=74)\end{array}$ & 5.0 & $\begin{array}{c}463 \\
(\mathrm{SE}=77)\end{array}$ & $\begin{array}{c}23 \\
(\mathrm{SE}=11)\end{array}$ \\
\hline Grants & $\ldots$ & $\ldots$ & $\ldots$ & 21.1 & $\begin{array}{c}670 \\
(\mathrm{SE}=64)\end{array}$ & $\begin{array}{c}141 \\
(\mathrm{SE}=21)\end{array}$ \\
\hline Casual employment & 19.9 & $\begin{array}{c}1104 \\
(\mathrm{SE}=318)\end{array}$ & $\begin{array}{c}219 \\
(\mathrm{SE}=71)\end{array}$ & 55 & $\begin{array}{c}3061 \\
(\mathrm{SE}=298)\end{array}$ & $\begin{array}{c}1684 \\
(\mathrm{SE}=187)\end{array}$ \\
\hline Pensions & 18 & $\begin{array}{c}217 \\
(\mathrm{SE}=27)\end{array}$ & $\begin{array}{c}39 \\
(\mathrm{SE}=8)\end{array}$ & 11.8 & $\begin{array}{c}1245 \\
(\mathrm{SE}=89)\end{array}$ & $\begin{array}{c}147 \\
(\mathrm{SE}=36)\end{array}$ \\
\hline Selling agricultural products & 16.8 & $\begin{array}{c}86 \\
(\mathrm{SE}=24)\end{array}$ & $\begin{array}{c}14 \\
(\mathrm{SE}=5)\end{array}$ & 1.4 & $\begin{array}{c}503 \\
(\mathrm{SE}=305)\end{array}$ & $\begin{array}{c}7 \\
(\mathrm{SE}=5)\end{array}$ \\
\hline Self-employment & 9.9 & $\begin{array}{c}975 \\
(\mathrm{SE}=332)\end{array}$ & $\begin{array}{c}97 \\
(\mathrm{SE}=40)\end{array}$ & 20.3 & $\begin{array}{c}2117 \\
(\mathrm{SE}=442)\end{array}$ & $\begin{array}{c}431 \\
(\mathrm{SE}=103)\end{array}$ \\
\hline Selling medicinal plants & 5.6 & $\begin{array}{c}37 \\
(\mathrm{SE}=17)\end{array}$ & $\begin{array}{c}2 \\
(\mathrm{SE}=1)\end{array}$ & & $\ldots$ & $\ldots$ \\
\hline Selling crafts & 3.1 & $\begin{array}{c}241 \\
(\mathrm{SE}=198)\end{array}$ & $\begin{array}{c}7 \\
(\mathrm{SE}=6)\end{array}$ & 0.4 & $\begin{array}{c}771 \\
(\mathrm{SE}=0)\end{array}$ & $\begin{array}{c}3 \\
(\mathrm{SE}=3)\end{array}$ \\
\hline Selling livestock & 3.1 & $\begin{array}{c}870 \\
(\mathrm{SE}=508)\end{array}$ & $\begin{array}{c}27 \\
(\mathrm{SE}=19)\end{array}$ & 9.3 & $\begin{array}{c}1208 \\
(\mathrm{SE}=268)\end{array}$ & $\begin{array}{c}65 \\
(\mathrm{SE}=21)\end{array}$ \\
\hline Selling firewood & 1.6 & $\begin{array}{c}14 \\
(\mathrm{SE}=0)\end{array}$ & $\begin{array}{c}0.14 \\
(\mathrm{SE}=0.09)\end{array}$ & & $\ldots$ & $\ldots$ \\
\hline
\end{tabular}

\section{Natural resource use in Mfuleni}

\section{Agriculture}

Of the households surveyed, $7.2 \%$ practiced agriculture and $6.1 \%$ had fields. Some households shared their fields with others, and agriculture was practiced on the wetland itself. The geometric mean field size in Mfuleni was 0.002 ha $(\mathrm{SD}=5.8 \mathrm{ha}$ ), and these tended to be small food gardens next to people's houses. The highest proportion of surveyed households practicing agriculture felt that the previous harvest had been a normal one. Although a range of vegetables was grown, the highest percentage of households grew spinach (Table 2).

\section{Natural resources}

A number of herbalists reported collecting imphepho (Helichrysum odoratissimum), which is used medicinally. This is not strictly a wetland species because it is also found in other areas. There were no crafts made in Mfuleni from harvested resources. Resources harvested around Mfuleni were firewood, medicinal plants, and wild vegetables (Table 3), although none of these were 
Table 2. Average agricultural production over the previous year around Letseng-la-Letsie and Mfuleni. \% $\mathrm{hh}=$ percentage of households growing the crop, $\mathrm{AH} / \mathrm{hh}=$ average harvest per growing household, $\mathrm{AH}=$ average harvest, AUP = average unit price in U.S. dollars, AGI = average gross income per year in U.S. dollars, ANI = average net income per year in U.S. dollars, and ACI = average cash income per year in U. S. dollars.

\begin{tabular}{|c|c|c|c|c|c|c|c|c|c|c|c|c|c|c|}
\hline \multirow[b]{2}{*}{ Crop } & \multicolumn{7}{|c|}{ Per farming household in Letseng-la-Letsie } & \multicolumn{7}{|c|}{ Per farming household in Mfuleni } \\
\hline & $\%$ hh & $\begin{array}{c}\mathrm{AH} / \\
\mathrm{hh}\end{array}$ & $\mathrm{AH}$ & AUP & AGI & ANI & ACI & $\%$ hh & $\begin{array}{l}\mathrm{AH} / \\
\mathrm{hh}\end{array}$ & $\mathrm{AH}$ & AUP & AGI & ANI & $\mathrm{ACI}$ \\
\hline Maize & 34.1 & $\begin{array}{c}309 \\
\mathrm{~kg}\end{array}$ & $\begin{array}{c}148 \\
\mathrm{~kg}\end{array}$ & 0.43 & 64 & 63 & 0.29 & 2.9 & $55 \mathrm{~kg}$ & $\begin{array}{c}31.5 \\
\mathrm{~kg}\end{array}$ & 0.64 & 20 & 19 & 3 \\
\hline Peas & 13 & $\begin{array}{c}396 \\
\mathrm{~kg}\end{array}$ & $72 \mathrm{~kg}$ & 0.49 & 35 & 33 & 0.14 & 1.1 & $7 \mathrm{~kg}$ & $2 \mathrm{~kg}$ & 0.43 & 0.70 & 0.70 & 0.57 \\
\hline Barley & 9.9 & $\begin{array}{l}147 \\
\mathrm{~kg}\end{array}$ & $21 \mathrm{~kg}$ & 0.20 & 4 & 3 & 0.71 & 0.3 & $10 \mathrm{~kg}$ & $7 \mathrm{~kg}$ & 0.57 & 4 & 3 & 0 \\
\hline Potatoes & 8.1 & $\begin{array}{l}872 \\
\mathrm{~kg}\end{array}$ & $99 \mathrm{~kg}$ & 0.29 & 28 & 27 & 14 & 3.2 & $52 \mathrm{~kg}$ & $33 \mathrm{~kg}$ & 1.07 & 36 & 34 & 9 \\
\hline Cabbages & 8 & $\begin{array}{c}202 \\
\mathrm{~kg}\end{array}$ & $23 \mathrm{~kg}$ & 0.40 & 9 & 8 & 3 & 2.5 & $23 \mathrm{~kg}$ & $10 \mathrm{~kg}$ & 0.57 & 6 & 4 & 3 \\
\hline Spinach & 1.9 & $\begin{array}{c}128 \\
\text { handf- } \\
\text { uls }\end{array}$ & $\begin{array}{c}3 \\
\text { handf- } \\
\text { uls }\end{array}$ & 0.36 & 1 & 1 & 0 & 3.6 & $\begin{array}{c}17 \\
\text { handf- } \\
\text { uls }\end{array}$ & $\begin{array}{c}13 \\
\text { handf- } \\
\text { uls }\end{array}$ & 0.43 & 5 & 4 & 3 \\
\hline Pumpkin & 0.6 & $1 \mathrm{~kg}$ & $\begin{array}{c}0.04 \\
\mathrm{~kg}\end{array}$ & 0.57 & 0.14 & 0.14 & 0 & 1.1 & $42 \mathrm{~kg}$ & $16 \mathrm{~kg}$ & 0.71 & 12 & 10 & 5 \\
\hline Onions & 0.6 & $\begin{array}{c}183 \\
\mathrm{~kg}\end{array}$ & $3 \mathrm{~kg}$ & 0.50 & 2 & 0.14 & 0 & $\cdots$ & $\ldots$ & $\cdots$ & $\ldots$ & $\cdots$ & $\cdots$ & $\ldots$ \\
\hline Wheat & 24.8 & $\begin{array}{l}125 \\
\mathrm{~kg}\end{array}$ & $44 \mathrm{~kg}$ & 0.40 & 18 & 16 & 2 & $\ldots$ & $\ldots$ & $\ldots$ & $\ldots$ & $\ldots$ & $\ldots$ & $\ldots$ \\
\hline Sorghum & 11.8 & $\begin{array}{c}183 \\
\mathrm{~kg}\end{array}$ & $30 \mathrm{~kg}$ & 0.57 & 17 & 16 & 0.14 & $\ldots$ & $\ldots$ & $\ldots$ & $\ldots$ & $\cdots$ & $\cdots$ & $\ldots$ \\
\hline Cannabis & 1.9 & $\begin{array}{l}647 \\
\mathrm{~kg}\end{array}$ & $17 \mathrm{~kg}$ & 1.86 & 31 & 30 & 31 & $\cdots$ & $\ldots$ & $\cdots$ & $\cdots$ & $\cdots$ & $\cdots$ & $\ldots$ \\
\hline Japanese radishes & 19.3 & $\begin{array}{l}552 \\
\mathrm{~kg}\end{array}$ & $\begin{array}{c}149 \\
\mathrm{~kg}\end{array}$ & 0.57 & 85 & 84 & 8 & $\ldots$ & $\ldots$ & $\ldots$ & $\ldots$ & $\cdots$ & $\cdots$ & $\ldots$ \\
\hline Beans & 6.8 & $66 \mathrm{~kg}$ & $6 \mathrm{~kg}$ & 0.50 & 3 & 2 & 1 & $\ldots$ & $\ldots$ & $\ldots$ & $\ldots$ & $\ldots$ & $\ldots$ & $\ldots$ \\
\hline Wheat straw & 11.2 & $\begin{array}{c}38 \\
\text { bundles }\end{array}$ & $\begin{array}{c}6 \\
\text { bundles }\end{array}$ & 2.86 & 17 & 16 & 0.14 & $\ldots$ & $\ldots$ & $\cdots$ & $\cdots$ & $\cdots$ & $\cdots$ & $\ldots$ \\
\hline Millet & $\cdots$ & $\cdots$ & $\cdots$ & $\ldots$ & $\ldots$ & $\cdots$ & $\ldots$ & 0.3 & $15 \mathrm{~kg}$ & $1 \mathrm{~kg}$ & 0.57 & 0.60 & 0.57 & 0.57 \\
\hline Rape & $\ldots$ & $\ldots$ & $\ldots$ & $\ldots$ & $\ldots$ & $\ldots$ & $\ldots$ & 1.4 & $55 \mathrm{~kg}$ & $12 \mathrm{~kg}$ & 0.50 & 6 & 5 & 6 \\
\hline Cauliflower & $\ldots$ & $\ldots$ & $\ldots$ & $\ldots$ & $\ldots$ & $\ldots$ & $\ldots$ & 0.3 & $6 \mathrm{~kg}$ & $0.4 \mathrm{~kg}$ & 0.57 & 0.30 & 0.29 & 0.29 \\
\hline Tomatoes & $\ldots$ & $\ldots$ & $\ldots$ & $\ldots$ & $\ldots$ & $\ldots$ & $\ldots$ & 1.4 & $35 \mathrm{~kg}$ & $10 \mathrm{~kg}$ & 0.50 & 5 & 4 & 0.14 \\
\hline
\end{tabular}




\begin{tabular}{|c|c|c|c|c|c|c|c|c|c|c|c|c|c|c|}
\hline Carrots & $\ldots$ & $\ldots$ & $\ldots$ & $\ldots$ & $\ldots$ & $\ldots$ & $\ldots$ & 0.7 & $20 \mathrm{~kg}$ & $1 \mathrm{~kg}$ & 0.43 & 0.50 & 0.57 & 0 \\
\hline Sweet potatoes & $\ldots$ & $\ldots$ & $\ldots$ & $\ldots$ & $\ldots$ & $\ldots$ & $\ldots$ & 0.3 & $0.5 \mathrm{~kg}$ & $\begin{array}{c}0.04 \\
\mathrm{~kg}\end{array}$ & 0.86 & 0.20 & 0.03 & 0 \\
\hline Butternut & $\ldots$ & $\ldots$ & $\ldots$ & $\ldots$ & $\ldots$ & $\ldots$ & $\ldots$ & 0.3 & $32 \mathrm{~kg}$ & $2 \mathrm{~kg}$ & 0.57 & 1 & 1 & 1 \\
\hline Turnips & $\ldots$ & $\ldots$ & $\ldots$ & $\ldots$ & $\ldots$ & $\ldots$ & $\ldots$ & 0.3 & $\begin{array}{l}100 \\
\mathrm{~kg}\end{array}$ & $7 \mathrm{~kg}$ & 0.21 & 2 & 2 & 2 \\
\hline Beetroot & $\ldots$ & $\ldots$ & $\ldots$ & $\ldots$ & $\ldots$ & $\ldots$ & $\ldots$ & 0.3 & $7.5 \mathrm{~kg}$ & $0.5 \mathrm{~kg}$ & 0.21 & 0.10 & 0.14 & 0 \\
\hline Total & $\ldots$ & $\ldots$ & $\ldots$ & $\ldots$ & 314.14 & 299.28 & 60.42 & $\ldots$ & $\ldots$ & $\ldots$ & $\ldots$ & 99.40 & 88.30 & 33.57 \\
\hline
\end{tabular}

specifically from wetlands. Medicinal plants and wild vegetables were for personal use, whereas firewood was sold by some households.

\section{Hunting}

Two households contained members who fished in the river. Only $1 \%$ of the households reported hunting on the wetlands and caught ducks and rabbits. Although reports of the relative number of animals hunted were low, households kept packs of dogs to hunt with, which suggested that they hunted regularly.

\section{Livestock}

Around Mfuleni, 8.6\% of the households surveyed owned livestock. The greatest proportion of livestock owners surveyed kept mixed herds of cattle and goats. Of the owners surveyed, $87.5 \%$ grazed their stock on the wetlands. The overall productivity of cattle and goats was higher than for sheep over the previous year (Table 5). Besides earning an income from selling livestock, $4.5 \%$ of the households obtained a small income from milk production. On average, $374 \mathrm{~L}$ of milk were collected monthly by cattle owners, yielding an average annual income of U.S. \$1290. A higher average volume of milk was produced by households in Mfuleni than in Letseng-la-Letsie. The households around Mfuleni did not obtain wool or mohair from their sheep and goats. There was a negative correlation between income and herd sizes for cattle $(r=-0.0331, P<0.01)$ and goats $(r$ $=-0.0628, P<0.05)$. There were insufficient sheep owners to do a correlative analysis of household cash income and sheep herd size. Again, because of the mixed composition of the herds, overall average incomes earned from livestock in general were calculated.

\section{Water use}

Fewer than $1 \%$ of the households surveyed in Mfuleni used water from the wetlands. Most used tap water for their domestic water needs, and those using tap water tended to consume the highest volume of water. About $4 \%$ of the households surveyed used river water for washing clothes.

\section{Dependence on wetlands}

A higher average income was earned by people in Mfuleni than those living round Letseng-la-Letsie, and this is reflected in the Human Development Index (Table 6). Although a higher proportion of people used the wetlands around Letseng-la-Letsie than around Mfuleni, the relative contribution of wetlands to people's incomes was lower. Many households near Letseng-la-Letsie practiced agriculture in the surrounding areas. In Mfuleni, wetlands tended to be the only open areas.

\section{Overall value of wetlands}

Estimated total incomes from livestock were higher around Letseng-la-Letsie than in Mfuleni (Table 7) despite the fact that prices in Mfuleni were $40 \%$ higher for cattle and $7 \%$ higher for sheep and goats. The incomes earned specifically from the wetland were lower, however, because there was other land available around Letseng-la-Letsie. In Mfuleni, the wetlands contributed more toward the total incomes earned because the amount of other land was limited. The estimated value of provisioning services per hectare was higher in Mfuleni than in Letseng-la-Letsie. Value added was higher than net income because it did not include capital and labor costs. 
Table 3. Average incomes from natural resources around Letseng-la-Letsie and Mfuleni over the previous year. Harvested units are head bundles for all but wild vegetables and medicines, which are measured as handfuls. $\% \mathrm{hh}=$ percentage of households, $\mathrm{AAH}=$ average amount harvested the previous year, $\mathrm{AAS}=$ average amount sold, AUP = average unit price in U.S. dollars, AGI = average gross income per year in U.S. dollars, ANI = average net income per year in U.S. dollars, and ACI = average cash income per year in U.S. dollars.

\begin{tabular}{|c|c|c|c|c|c|c|c|c|c|c|c|c|c|c|c|c|}
\hline \multirow[b]{2}{*}{$\begin{array}{l}\text { Resource } \\
\text { sold }\end{array}$} & \multicolumn{8}{|c|}{ Per farming household in Letseng-la-Letsie } & \multicolumn{8}{|c|}{ Per farming household in Mfuleni } \\
\hline & $\begin{array}{l}\text { \%hh } \\
\text { har- } \\
\text { ves- } \\
\text { ting }\end{array}$ & AAH & $\begin{array}{l}\text { \%hh } \\
\text { sell- } \\
\text { ing }\end{array}$ & AAS & AVP & AGI & ANI & $\overline{\mathrm{ACI}}$ & $\begin{array}{l}\text { \%hh } \\
\text { harv- } \\
\text { esting }\end{array}$ & AAH & $\begin{array}{l}\text { \%hh } \\
\text { sell- } \\
\text { ing }\end{array}$ & AAS & AVP & AGI & ANI & $\mathrm{ACI}$ \\
\hline Firewood & 82 & 184 & 5 & 2 & 1.70 & 313 & 312 & 3 & 14 & $\begin{array}{c}1553 \\
\mathrm{~kg}\end{array}$ & 0.3 & $\begin{array}{l}128 \\
\mathrm{~kg}\end{array}$ & 2 & 2662 & 2661 & 220 \\
\hline Reeds & 1.9 & 3 & 1.2 & 2 & 1.43 & 4 & 3 & 3 & $\ldots$ & $\ldots$ & $\ldots$ & $\ldots$ & $\ldots$ & $\ldots$ & $\ldots$ & $\ldots$ \\
\hline Grass & 9.9 & 7 & 2.5 & 1 & 1.43 & 10 & 9 & 1 & $\ldots$ & $\ldots$ & $\ldots$ & $\ldots$ & $\ldots$ & $\ldots$ & $\ldots$ & $\ldots$ \\
\hline Sedge & 11.2 & 2 & 1.2 & 1 & 1.43 & 3 & 2 & 1 & $\ldots$ & $\ldots$ & $\ldots$ & $\ldots$ & $\ldots$ & $\ldots$ & $\ldots$ & $\ldots$ \\
\hline Wild vegetables & 65.2 & 1254 & & $\ldots$ & 1.14 & 1433 & 1432 & $\ldots$ & 0.4 & $5 \mathrm{~kg}$ & & $\ldots$ & 1 & 5 & 4 & $\ldots$ \\
\hline Natural medicines & 28.6 & $\begin{array}{c}74 \\
\text { han- } \\
\text { dfuls }\end{array}$ & 2.5 & 7 & 1.43 & 106 & 104 & 10 & 1.4 & $\begin{array}{c}33 \\
\text { han- } \\
\text { dfuls }\end{array}$ & & $\ldots$ & 1 & 30 & 29 & $\ldots$ \\
\hline
\end{tabular}

\section{DISCUSSION}

\section{General livelihood activities in Letseng-la- Letsie and Mfuleni}

Around Letseng-la-Letsie, the main incomes were from casual employment and remittances. Households with lower incomes tended to engage in agriculture and harvest natural resources. Lowerincome households in Letseng-la-Letsie probably diversify their activities to reduce risk and ensure a sustainable income (Shackleton et al. 2001, Block and Webb 2001). Fewer households in Letseng-laLetsie included members who were employed. In Mfuleni, the main sources of income were casual employment and grants, and households relied less on agriculture and natural resources. In both areas, crops that were harvested contributed mainly to household subsistence. This was also found in the Okavango, in which only a small proportion of crops are sold (Turpie et al. 2006).
Few natural resources were harvested by either of the two communities apart from firewood, which many households in both areas relied on for heating and cooking. In both areas, the sale of crafts was ranked low as a source of income in contrast to other parts of Africa, in which harvesting natural resources for crafting is a major contribution to livelihoods (Schuyt 2005, Shackleton and Campbell 2007). At Letseng-la-Letsie, the wetland vegetation is lacking in diversity and in the species normally used for craft making (Grab and Morris 1997) and is nearly all grazed. At Mfuleni, reliance on the harvesting of natural resources was relatively low because of the availability of substitutes in the urban environment.

More households reared livestock in rural Letsengla-Letsie than in peri-urban Mfuleni, as would be expected from the difference in rangeland area available. Around Letseng-la-Letsie, there was a correlation between household income and number of sheep, the dominant form of livestock. This is consistent with a situation in which livestock 
Table 4. Animals caught around the Letseng-la-Letsie and Mfuleni wetlands. ANC = average number caught by hunting households, EVA = estimated value per animal in U.S. dollars, AGI = average gross income in U.S. dollars, and ANI = average net income in U.S. dollars.

\begin{tabular}{lccccc}
\hline \hline & \multicolumn{9}{c}{ Letseng-la-Letsie } & \multirow{2}{*}{ Mfuleni } \\
\cline { 2 - 5 } \cline { 3 - 5 } Animal & ANC & EVA & AGI & ANI n & \multirow{2}{*}{ ANC } \\
\hline Rabbits & 0.6 & 2 & 1 & 1 & 0.01 \\
Hares & 0.8 & 2 & 2 & 1 & \\
Antelope & 0.1 & 7 & 11 & & \\
Francolins & 0.3 & 2 & 1 & 1 & \\
Rock rabbits & 0.1 & 2 & 0.30 & 0.30 & \\
Ducks & & $\ldots$ & $\ldots$ & $\ldots$ & \\
Other birds & 0.3 & 2 & 1 & 1 & \\
\hline
\end{tabular}

provide multiple social benefits, including a wealth store function (Meltzer 1995, Grab and Morris 1997, Dovie et al. 2005, Shackleton et al. 2005), and in which high stocking rates are favored over production. Small livestock also yield better returns from reproduction (Meltzer 1995) and generate a substantial income from mohair and wool (Dovie et al. 2006). Thus, livestock in this area may generate better incomes than in other communal livestock systems in which production values are typically low (e.g. Meltzer 1995, Turpie et al. 1999, Turpie et al. 2006). Around Mfuleni, on the other hand, there was a negative correlation between household income and numbers of livestock, which are dominated by cattle, and households with higher incomes did not keep livestock. This suggests that lower-income households are more dependent on livestock for their livelihoods. In both areas, the limited degree of control over grazing, coupled with the objective of maximizing animal numbers rather than production, means that the value of grazing is probably lower than its potential. This activity probably compromises ecosystem health, the production of natural resources, and ecosystem functions.

\section{Provisioning services and incomes derived from the wetlands}

The scarcity of high-quality grazing is one of the greatest limiting factors affecting livestock production in Africa (Meltzer 1995). Wetlands are preferentially grazed by both small and large stock (Grab and Morris 1997), and grazing is a common use of wetlands in the region (Palmer et al. 2002, Bisaro 2007). Alpine wetlands in Lesotho have been found to be particularly important in providing forage during the change of seasons when surrounding grasslands are dry (Grab and Morris 1997). The timing of wetlands grazing may be as important as the amount of fodder they produce, and they may play a major role in maintaining stock numbers and reducing mortality in times of drought. A negative aspect of grazing on wetland areas is that wetlands can increase the risk of livestock parasite infections and the occurrence of potentially fatal foot rot (Begg 1986).

In Letseng-la-Letsie, herders reported that the wetland provided the best grazing in the region. It contributed an estimated $5 \%$, or U.S. $\$ 35$, of the average livestock owner's net income. At Mfuleni, the wetland contributed an average of $90 \%$ of net income, or U.S. \$1916, from livestock. Estimates of incomes from grazing of wetlands vary depending on wetland type and context, particularly with regard to the proportion of grazing derived 
Table 5. Average incomes of livestock owners around Letseng-la-Letsie over the past year; \%hh = percentage of households.

\begin{tabular}{|c|c|c|c|c|c|c|c|c|}
\hline & \multicolumn{4}{|c|}{ Letseng-la-Letsie } & \multicolumn{4}{|c|}{ Mfuleni } \\
\hline & $\begin{array}{l}\text { Livestock } \\
\text { in general }\end{array}$ & Cattle & Goats & Sheep & $\begin{array}{l}\text { Livestock } \\
\text { in general }\end{array}$ & Cattle & Goats & Sheep \\
\hline$\%$ hh & 62.1 & 47.2 & 32.3 & 39 & 8.6 & 7.2 & 5.4 & 0.7 \\
\hline $\begin{array}{l}\text { Average number } \\
\text { owned }\end{array}$ & $\ldots$ & 5.6 & 11.6 & 30.3 & 20.5 & $\ldots$ & 14.7 & 30.3 \\
\hline $\begin{array}{l}\text { Average number } \\
\text { slaughtered }\end{array}$ & $\ldots$ & 1.1 & 0.6 & 1.1 & ... & 0.5 & 0.8 & 1.5 \\
\hline $\begin{array}{l}\text { Average number to } \\
\text { herders }\end{array}$ & $\ldots$ & 0.01 & 0.2 & 0.4 & $\ldots$ & 0.05 & 0.2 & 0.4 \\
\hline $\begin{array}{l}\text { Average number } \\
\text { sold }\end{array}$ & $\ldots$ & 0.2 & & 0.8 & $\ldots$ & 2.1 & 1.9 & \\
\hline $\begin{array}{l}\text { Average annual } \\
\text { production }\end{array}$ & $\ldots$ & 1.4 & 0.8 & 2.3 & ... & 2.7 & 2.7 & 1.8 \\
\hline Price (U.S. \$) & $\ldots$ & 357 & 100 & 100 & $\ldots$ & 500 & 107 & 107 \\
\hline $\begin{array}{l}\text { Average gross } \\
\text { income (U.S. \$/yr) }\end{array}$ & 2360 & 1777 & 154 & 429 & 4360 & 3920 & 289 & 150 \\
\hline $\begin{array}{l}\text { Average cash } \\
\text { income (U.S. \$/yr) }\end{array}$ & 166 & 86 & & 80 & 1254 & 1050 & 204 & \\
\hline $\begin{array}{l}\text { Average net income } \\
\text { (U.S. \$/yr) }\end{array}$ & 714 & $\ldots$ & $\ldots$ & $\ldots$ & 2129 & $\ldots$ & $\ldots$ & $\ldots$ \\
\hline
\end{tabular}

from the wetland as well as the proportional ownership of cattle. For the Barotse floodplain in the Zambezi Basin, the estimated net household income from grazing livestock on the floodplain was U.S. \$120/yr (Turpie et al. 1999). Although also a rural setting, the floodplain area formed a much greater proportion of the landscape. For a much smaller wetland in Craigieburn in the Mpumalanga Province of South Africa, livestock owners derived a relatively high proportion of grazing from the wetland, which was estimated to provide a net income of U.S. \$1296/household (S. Pollard, D. Kotze, and G. Ferrari, unpublished mansucript). At Mfuleni, livestock ownership is concentrated in a small proportion of households, and these households rely heavily on the wetland.

Households did not use Letseng-la-Letsie for fishing and domestic water consumption. In
Mfuleni, fishing was restricted to the Kuils River, and only a small proportion of surveyed households used water from wetlands for domestic consumption. In both areas, some households derived a small income from hunting on the wetlands. Because of the illegal nature of this activity, hunting values may have been underestimated in this study.

Wetlands are also important because they allow for year-round crop production by providing water in dry periods and enhance yields by increasing soil nutrient and sediment levels (Emerton et al. 1999). A higher yield of crops from wetland areas can give households greater food security and improve their livelihoods. However, if wetlands are not drained, overall crop yields may be affected by excessive moisture. Certain crops are better suited to growing in wet conditions than others. At Mfuleni, 
Table 6. Average incomes earned in Letseng-la-Letsie and Mfuleni and their relative dependency upon the wetlands.

\begin{tabular}{lcc}
\hline \hline & Letseng-la-Letsie & Mfuleni \\
\hline Average annual income in area (U.S. \$) & 886 & 2765 \\
Population density (people/km²) & 66 & 1600 \\
Human Development Index & $0.549^{\dagger}$ & $0.76^{\ddagger}$ \\
Percentage of households using wetland & 65 & 12.8 \\
Average annual income of wetland users (U.S. \$) & 826 & 2454 \\
Average annual income from wetlands (U.S. \$) & 66 & 2003 \\
Percentage of income of wetland users from wetlands & 8.0 & 81.6 \\
\hline
\end{tabular}

UNDP (2007)

${ }^{\ddagger}$ Statistics South Africa (2001b)

vegetables were cultivated mainly for subsistence, and only a small proportion was sold. Subsistence agriculture generates food at a lower cost than in markets, a value of natural ecosystems that is often overlooked (Delang 2006a,b). Farming households generated at least U.S. \$100/yr from the Mfuleni wetlands. In Craigieburn, the average farming household earned U.S. \$182/yr from wetland agriculture (S. Pollard, D. Kotze, and G. Ferrari, unpublished manuscript) and, in Mbongolwane in KwaZulu-Natal in South Africa, farming households earned on average U.S. \$39/yr from wetland cultivation (D. Kotze, B. Memela, N. Fuzani, and M. Thobela, unpublished manuscript). The overall yields and size of people's fields in Mfuleni were small in comparison to other wetland areas in Africa.

\section{Dependence on the wetlands for income, risk spreading, and as a safety net}

As well as the generation of income per se, wetlands can provide an opportunity to spread risk as well as functioning as a safety net, both of which are important to people's livelihoods in different ways. Many wetlands have been shown to provide substantial value in spreading risk by providing resources that enable households to broaden their activity portfolios (Turpie et al. 1999, Schuyt 2005).
This was not the case for the wetlands in this study. Letseng-la-Letsie essentially adds to the productivity of only one of the activities typically undertaken by local households. Nevertheless, when the contribution of the wetland to productivity during the dry season was considered, it was apparent that the wetland was important for risk spreading and income smoothing. In Mfuleni, households did not typically engage in multiple activities, and the wetland did not form part of a risk-spreading strategy. However, because it was an open-access resource in an urban area, it did provide an opportunity for newcomers, e.g., job seekers, to derive a livelihood, thus performing more of a safety-net function. The safety-net value of the wetlands is much more far-reaching than the simple estimates of income provided in this study. This function eases the burden on the state to provide social security but comes at the potential cost of ecosystem health.

The two areas provide an interesting contrast in that one represents a situation in which a high proportion of local households derive a small proportion of their income from the wetland, whereas the reverse is true for the other community, which also has a higher average income in general. This begs the question as to which community is more dependent on the wetland. In Mfuleni, if the wetland were lost there are other occupations that people could turn 
Table 7. Estimated total incomes earned and incomes from wetland provisioning services for Letseng-laLetsie (819 ha) and Mfuleni (310 ha).

\begin{tabular}{|c|c|c|c|c|c|c|}
\hline & \multicolumn{3}{|c|}{ Letseng-la-Letsie } & \multicolumn{3}{|c|}{ Mfuleni } \\
\hline & Livestock & Hunting & Total & Livestock & Crops & Total \\
\hline \multicolumn{7}{|l|}{ Total } \\
\hline Percentage of households & 24.2 & 5 & & 8.5 & 7.1 & \\
\hline Estimated number of households & 986 & 203 & & 95 & 79 & \\
\hline Gross income (U.S. \$1000) & 2329 & 1 & 2330 & 414 & 8 & 422 \\
\hline Net income (U.S. \$1000) & 705 & 1 & 706 & 202 & 7 & 209 \\
\hline Value added (U.S. \$1000) & 3593 & 1 & 3594 & 600 & 7 & 607 \\
\hline \multicolumn{7}{|l|}{ From wetland } \\
\hline Gross income (U.S. \$1000) & 116 & 1 & 117 & 373 & 8 & 381 \\
\hline Net income (U.S. \$1000) & 35 & 1 & 36 & 182 & 7 & 189 \\
\hline Value added (U.S. \$1000) & 180 & 1 & 181 & 540 & 7 & 547 \\
\hline Value added/ha & 219 & 1 & 220 & 1742 & 23 & 1765 \\
\hline
\end{tabular}

to. The overall social cost of wetland loss or degradation is therefore likely to be higher around Letseng-la-Letsie than Mfuleni, although the cost to individuals would be greater in Mfuleni. In neither case could the community be said to be highly dependent on the wetlands.

When households are completely dependent on natural resources for their livelihoods, it is a sign of extreme poverty and deprivation (Béné 2003). The percentage of households using a wetland may be a good indicator of the importance of the wetland to people's livelihoods (Kangalawe and Liwenga 2005). In a study of the Yala swamp in Kenya, it was found that $86 \%$ of the population relied on the wetland for the provision of building materials such as clay, sand, wood, and papyrus (Schuyt 2005). In Craigieburn in South Africa, it was found that $73 \%$ of the households around the wetland made use of the wetland provisioning services (S. Pollard, D. Kotze, and G. Ferrari, unpublished manuscript). Of these households, $63 \%$ were from the lowest wealth group and received only occasional incomes, with many dependents relying on this. By identifying the number of people using wetlands and their overall dependence on them, decision makers can see how the loss of wetlands could affect the welfare of the communities living around them. The wetlands in Mfuleni contribute more to individual livelihoods than does the rural wetland in Letseng-la-Letsie. However, in Letseng-la-Letsie, a larger number of people rely on the wetland, so that the loss of the wetland would have a greater regional impact.

\section{Overall value of the wetlands}

The value of Letseng-la-Letsie (U.S. \$220 $\cdot \mathrm{ha}^{-1} \cdot \mathrm{yr}^{-1}$ ) falls within the range of most estimated values for rural wetlands elsewhere. In the Hadejia-Nguru wetland in Nigeria, the annual value derived from agriculture, fishing, and firewood provision was approximately U.S. \$34-54/ha (Barbier et al. 1997). The Nakivubo wetland in Uganda was estimated to 
generate approximately U.S. \$500/ha annually from agriculture (Emerton et al. 1999). Wetlands in the Zambezi Basin ranged in grazing value from U.S. \$16/ha in the Barotse wetland to U.S. \$97/ha in the Caprivi wetland (Turpie et al. 1999). Although crop cultivation in the Lower Shire Wetlands in the Zambezi Basin contributed a high income of U.S. $\$ 203 /$ ha, other wetlands within the basin had lower agricultural returns. In the Olifants River catchment in South Africa, it was estimated that floodplains generated incomes of U.S. \$1-14.ha ${ }^{-1} \cdot \mathrm{yr}^{-1}$ from harvestable resources (Palmer et al. 2002). Seeps were predicted to generate higher annual incomes of U.S. \$260-360/ha because they were used for agriculture. An estimate of the annual value from wetlands in this region for grazing was U.S. \$257343/ha. The value of wetlands in Mfuleni (U.S. $\$ 1742 \cdot \mathrm{ha}^{-1} \cdot \mathrm{yr}^{-1}$ ) was far higher. This is probably because of the more intensive use of Mfuleni due to population pressure, coupled with the higher incomes derived per unit of production as a result of being closer to markets.

The results reported may be affected by inaccuracies in reporting by households, which relied on the respondents' recall of resources harvested and incomes derived over the previous year. Values reported here were for 2007, but these are likely to vary over time depending on resource availability, socioeconomic factors, and land management practices. In the case of Letseng-la-Letsie, households stated that the harvest was lower than in previous years, implying that higher economic values may potentially be obtained. In Mfuleni, households stated that the harvests were normal compared with those of other years.

\section{Are the wetland values sustainable?}

Uses that maximize private returns may not be environmentally sustainable, and it is important to consider the longer-term implications of these activities (Kotze and Breen 1996, Huitric 2005). The cultivation of wetlands may alter their regulatory function by reducing their water storage capacity, resulting in more variable stream flows (Dixon and Wood 2003). It is worth considering whether some activities will have an irreversible effect and detract from the future value of wetlands.

There may also be a negative relationship between social and ecological resilience, especially in situations in which communities are highly dependent upon natural resources for their livelihoods (Adger 2000). Indeed, the Letseng-laLetsie and Mfuleni wetlands are already degraded. Letseng-la-Letsie has been modified by dam construction and overgrazing. The wetlands around Mfuleni have been polluted, hydrologically altered, and encroached upon by urban development. Furthermore, the number of people using the wetlands in Mfuleni continues to increase as more people migrate to the area.

In both areas, there is little control over resource use. In Letseng-la-Letsie, for instance, although the chiefs ostensibly control grazing, there are often power disputes between chiefs and village development councils over the regulation of open access to resources (Letsela et al. 2002). If stricter property rights were introduced and the number of people using the wetlands was limited, the value generated might be higher and more sustainable, but possibly at the cost of the safety-net function provided by the wetland. At times, the direct-use value of open access resources may be lower than the value of what they contribute as a safety net to communities during times of financial need such as retrenchment or the death of a breadwinner (Shackleton et al. 2001). The wetlands in Mfuleni may play an important role in supporting the unemployed. Removing open access to the wetlands would probably affect the poorest households the most, because they are less likely to have alternative private resources.

The level of use that is desirable will ultimately depend on the trade-off between productive value through sustainable use and the degree to which value is distributed to those most in need. The scenario presented in this paper, in which many households have a low dependence upon the wetland for their livelihoods compared with a few households that are highly dependent, offers a challenge when estimating the economic value of wetlands. The overall social cost to the whole community when wetlands are lost needs to be considered. In developing a protocol for valuing wetlands it would therefore be important to consider how diversified local community livelihoods are and their other potential safety nets in times of financial stress. The number of people using the wetland may eventually reach a critical point at which the ecological resilience will be surpassed and signs of wetland degradation should therefore be monitored and incorporated into the valuation. 


\section{CONCLUSION}

The main use by the surrounding communities of the wetlands in both Letseng-la-Letsie and Mfuleni was for livestock grazing. Although the local inhabitants of Mfuleni also took advantage of other provisioning services such as wildlife for hunting and land for crop cultivation, these activities were minor and did not generate significant income to households. Nevertheless, the value of the wetlands was comparable to those of other wetland systems in Africa. The rural Letseng-la-Letsie wetland performed a risk-spreading function for a large proportion of the community by contributing to income during the dry season. The peri-urban Mfuleni wetland performed a safety-net function for a small proportion of the community by offering income opportunities to unemployed migrants. This was because of the controlled vs. open access nature of the two wetlands, respectively, as well as the nature of the communities. In this respect, it was difficult to determine which community was more dependent on wetlands.

There is a need for more studies to be conducted on wetlands in southern Africa and for a standard protocol to make these studies comparable. Wetland valuation studies need to put values in perspective by describing their role in income smoothing as well as their contribution to overall household income and the sustainability of this income. Futhermore, a way needs to be found to express the safety-net value of wetlands, because descriptions of income derived may underestimate the importance of this function. Once a wider database has been established, it may be possible to develop more rapid ways of estimating the value of wetlands using key indicators and characteristics. This would be a great asset, because it is expensive to undertake a comprehensive study of wetland value and there is little information available. If more data were available for a wider range of wetlands in southern Africa, it would be useful to see how wetland value varies with wetland characteristics.

Responses to this article can be read online at: http://www.ecologyandsociety.org/voll4/iss2/art18/ responses/

\section{Acknowledgments:}

This project was funded by the Water Research Commission, South Africa. Guidance and support from T. Leiman, H. Malan, J. Day, and D. Kotze were much appreciated. Thanks are extended to $N$. Scrovronick and the enumerators who helped collect data.

\section{LITERATURE CITED}

Adaya, A. L., H. Bdliya, H. Bitrus, M. Danjaji, D. Eaton, M. B. Gambo, M. Goggobe, A. Makinta, D. Okali, A. D. Omoluabi, G. Polet, M. Salisu, S. S. Sanusi, M. T. Sarch, and M. Shuaibu. 1997. Local-level assessment of the economic importance of wild resources in the Hadejia-Nguru Wetlands, Nigeria. Hidden Harvest Project, Research Series Volume 3, No. 3. International Institute for Environment and Development, London, UK.

Adger, N. W. 2000. Social and ecological resilience: Are they related? Progress in Human Geography 24 (3):347-364.

Barbier, E. B. 1993. Sustainable use of wetlands; valuing tropical wetland benefits: economic methodologies and applications. Geographical Journal 159(1):22-32.

Barbier, E. B., M. Acreman, and D. Knowler. 1997. Economic valuation of wetlands: a guide for policy makers and planners. Ramsar Convention Bureau, Gland, Switzerland.

Begg, G. 1986. The wetlands of Natal. Part 1: an overview of their extent, role and present status. Natal Town and Regional Planning Report, Volume 68. Natal Town and Regional Planning Commission, Natal, South Africa.

Béné, C. 2003. When fishery rhymes with poverty: a first step beyond the old paradigm on poverty in small-scale fisheries. World Development 31:949-975.

Bisaro, S. 2007. Formal and informal institutions in the wetlands of the Lesotho Highlands. in C. PahlWostl, P. Kabat, and J. Moltgen, editors. 
Proceedings of the International Conference on Adaptive and Integrated Water Management: coping with complexity and uncertainty. (Basel, 2007). Springer, Berlin, Germany.

Block, S., and P. Webb. 2001. The dynamics of livelihood diversification in post-famine Ethiopia. Food Policy 26:333-350.

Delang, C. O. 2006a. Economic valuation of nonmarketed wild edible plants in Thailand. Environmental Conservation 32:285-287.

Delang, C. O. 2006b. Not just minor forest products: the economic rationale for the consumption of wild food plants by subsistence farmers. Ecological Economics 59(1):64-73.

Dixon, A. B., and A. P. Wood. 2003. Wetland cultivation and hydrological management in eastern Africa: matching community and hydrological needs through sustainable wetland use. Natural Resources Forum 27(2):117-129.

Dixon, J., and M. Ramutsindela. 2006. Urban resettlement and environmental justice in Cape Town. Cities 23(2):129-139.

Dovie, D. B. K., E. T. F. Witkowski, and C. M. Shackleton. 2005. In the field: monetary valuation of livelihoods for understanding the composition and complexity of rural households. Agriculture and Human Values 22:87-103.

Dovie, D. B. K., C. M. Shackleton, and E. T. F. Witkowski. 2006. Valuation of communal area livestock benefits, rural livelihoods and related policy issues. Land Use Policy 23(3):260-271.

Emerton, L., L. Iyango, P. Luwum, and A. Malinga. 1999. The present economic value of Nakivubo urban wetland, Uganda. IUCN, Eastern Africa Regional Office, Nairobi, Kenya. Available online at : http://www.subpesca.cl/taller/documentos/ valoracion $\% 20 \mathrm{de} \% 20$ beneficios $\% 20$ ecosistemicos/ Reference material/IUCN\%5CEmerton wetland uganda. pdf.

Gittinger, J. P. 1982. Economic analysis of agricultural projects. Second edition. Johns Hopkins University Press, Baltimore, Maryland, USA.
Grab, S., and C. Morris. 1997. A threatened resource: Lesotho's alpine wetlands, unique in many ways, are facing a complexity of threats. African Wildlife 51(3):14-16.

Huitric, M. 2005. Lobster and conch fisheries of Belize: a history of sequential exploitation. Ecology and Society 10(1): 21. [online] URL: http://www.e cologyandsociety.org/vol10/iss1/art21/.

Kangalawe, R. Y. M., and E. T. Liwenga. 2005. Livelihoods in the wetlands of Kilombero Valley in Tanzania: opportunities and challenges to integrated water resource management. Physics and Chemistry of the Earth 30:968-975.

Kotze, D., and C. M. Breen. 1994. Agricultural land use impacts on wetland functional values. WRC Report No. 501/3/94. Water Research Commission, Pretoria, South Africa.

Kotze, D., and C. M. Breen. 1996. Wetlands and people: What values do wetlands have for us and how are these values affected by our land-use activities? Wetland Use Booklet No. 1. Share-net, Umgeni Valley, South Africa.

Letsela, T., K. Balkwill, and E. T. F. Witkowksi. 2002. Conservation and sustainable livelihoods in Bokong and Tsehlanyane in Lesotho. Pages 192-200 in T. A. Benjaminsen, B. Cousins, and L. Thompson, editors. Contested resources: challenges to governance of natural resources in Southern Africa. University of the Western Cape, Programme for Land and Agrarian Studies, South Africa.

Meltzer, M. I. 1995. Livestock in Africa: the economics of ownership and production, and the potential for improvement. Agriculture and Human Values 12(2):4-18.

Millennium Ecosystem Assessment. 2005. Ecosystems and human well-being: synthesis. Island Press, Washington, D.C., USA.

Ministry of Natural Resources. 2006. Conservation and rehabilitation of wetlands in Lesotho. Ministry of Natural Resources, Department of Water Affairs, Maseru, Lesotho.

Morgenthal, T. L., T. Newby, H. J. C. Smith, and D. J. Pretorius. 2004. Developing and refinement of a grazing capacity map for South Africa using 
NOAA (AVHRR) satellite derived data. Report GW/ A/2004/66. Agricultural Research Commission, Pretoria, South Africa.

Morris, C. D, T. S. Bolene, and N. M. Tainton. 1989. Report on investigations of fire and grazing regimes and conservation needs of the eastern alpine catchments of Lesotho. University of Northern Province, Department of Grassland Science.

Nichols, P. 1991. Social survey methods: a fieldguide for development workers. Development Guidelines, Volume 6. Oxfam, Oxford, UK.

Palmer, R. W., J. Turpie, G. C. Marnewick, and A .L. Batchelor. 2002. Ecological and economic evaluation of wetlands in the Upper Olifants River Catchment, South Africa. WRC Report Number 1162/02. Water Research Commission, Pretoria, South Africa.

Sathirathai, S. 1997. Economic valuation of mangroves and the roles of local communities in the conservation of natural resources: case study of Surat Thani, South of Thailand. Environmental Educators' Provincial Specialist Association, Ottawa, Ontario, Canada.

Schuyt, K. D. 2005. Economic consequences of wetland degradation for local populations in Africa. Ecological Economics 53:177-190.

Shackleton, S. E., and B. M. Campbell. 2007. The traditional broom trade in Bushbukridge, South Africa: helping poor women cope with adversity. Economic Botany 61(3):256-268.

Shackleton, C. M., S. E. Shackleton, and B. Cousins. 2001. The role of land-based strategies in rural livelihoods: the contribution of arable production, animal husbandry and natural resource harvesting in communal areas in South Africa. Development South Africa 18(5):581-604.

Shackleton, C. M., S. E. Shackleton, T. R. Netshiluvhi, and F. R. Mathabela. 2005. The contribution and direct-use value of livestock to rural livelihoods in the Sand River catchment, South Africa. African Journal of Range and Forage Science 22(2):127-140.
Shand, N., and C. Nicks. 1999. Kuils River Metropolitan Open Space System (MOSS). Volume 1: final report. Report Number 2913. Ninham Shand, Cape Town, South Africa.

Smit, L., and K. Wiseman. 2001. Environmental resource economics as a tool for environmental management in the City of Cape Town. Pages 190-218 in Forum for Economics and Environment: first conference proceedings. Available online at: http://www.econ4env.co.za/archives/ecodivide/Theme4e. pdf.

Statistics South Africa. 2001a. City of Cape Town: census 2001: Mfuleni. Statistics South Africa, Pretoria, South Africa. Available online at: http://w ww.capetown.gov.za/en/stats/2001census/Documents/ Mfuleni.htm.

Statistics South Africa. 2001b. Human development index. Statistics South Africa, Pretoria, South Africa. Available online at: http://www.statssa.gov. $\mathrm{za} /$ publications/P0015/P00151980.pdf.

Terer, T., G. G. Ndiritu, and N. N. Gichuki. 2004. Socio-economic values and traditional strategies of managing wetland resources in Lower Tana River, Kenya. Hydrobiologia 527:3-14.

Turner, R. K., J. C. J. M. van den Bergh, T. Soderqvist, A. Barendregt, J. van der Straaten, E. Maltby, and E. C. van Ierland. 2000. Ecological-economic analysis of wetlands: scientific integration for management and policy. Ecological Economics 35:7-23.

Turpie, J. 2000. The use and value of natural resources of the Rufiji Floodplain and Delta, Tanzania. IUCN East Africa Regional Office, Nairobi, Kenya.

Turpie, J., J. Barnes, J. Arntzen, B. Nherera, G. Lange, and B. Buzwani. 2006. Economic value of the Okavango Delta, Botswana, and implications for management. International Union for the Conservation of Nature, Gland, Switzerland, and Department of Environmental Affairs, Gabarone, Switzerland.

Turpie, J., A. Joubert, H. van Zyl, B. Harding, and T. Leiman. 2001. Valuation of open space in the Cape Metropolitan Area: a pilot study to 
demonstrate the application of environmental and resource economics methods for the assessment of open space values in two case study areas: Metro South and Metro South-east. City of Cape Town, Cape Town, South Africa.

Turpie, J., B. Smith, L. Emerton, and J. Barnes. 1999. Economic value of the Zambezi Basin wetlands. IUCN Regional Office for Southern Africa. Harare, South Africa

UNDP. 2007. Lesotho-GDP_all series. Available online at: http://millenniumindicators.un.org/unsd/ snaama/resultsCountry.asp?Country $=426$.

Wynberg, R. 2002. A decade of biodiversity conservation and use in South Africa: tracking progress from the Rio Earth Summit to the Johannesburg World Summit on Sustainable Development. South African Journal of

Science 98:233-243.

Zunckel, K. 2003. Managing and conserving southern African grasslands with high endemism: the Maloti-Drakensberg Transfrontier Conservation and Development Programme. Mountain Research and Development 23(2):113-118. 